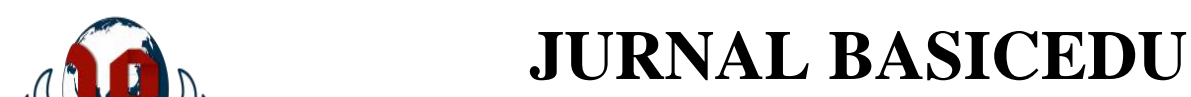

Volume 5 Nomor 4 Tahun 2021 Halaman 2270 - 2277

Research \& Learning in Elementary Education https://jbasic.org/index.php/basicedu

PAHLAWAN

\title{
Analisis Program Penguatan Pendidikan Karakter pada Mata Pelajaran Pendidikan Agama Islam (PAI) di Sekolah Dasar
}

\author{
Titin Lestari Solehat ${ }^{1 凶}$, Zaka Hadikusuma Ramadan ${ }^{2}$ \\ Pendidikan Dasar, Universitas Islam Riau, Indonesia ${ }^{1,2}$ \\ E-mail: titinlestari@student.uir.ac.id ${ }^{1}$, zakahadi@edu.uir.ac.id ${ }^{2}$
}

\begin{abstract}
Abstrak
Tujuan dari riset ini mendeskripsikan implementasi Program Pendidikan Karakter (PPK) pada mata pelajaran PAI di tinjau dari Perancanaan, Pelaksanaan, dan evaluasi di Sekolah Dasar. Metode yang digunakan dalam penelitian ini adalah deskriptif kualitatif dengan menggunakan teknik pengumpulan data melalui wawancara, observasi dan dokumentasi. Kemudian teknik analisis data yang digunakan yaitu reduksi data, penyajian data dan kesimpulan. Hasil pada penelitian ini Dalam membuat perencanaan pendidikan karakter mata pelajaran pendidikan agama Islam, guru banyak mencantumkan nilai-nilai karakter yang diharapkan di dalam rencana pelaksanaan pembelajaran (RPP).Persiapan yang ditetapkan dan difasilitasi oleh sekolah adalah seperti membaca surah pendek dan yaasin pada hari Jum'at, gotong royong, takziah bagi yang mengalami kemalangan, serta penyediaan air bersih dan alat shalat untuk melakukan praktek shalat di sekolah. Bentuk evaluasi yang dilakukan bagi peserta didik adalah dengan pengerjaan Lembar Kerja Siswa (LKS) dan praktek membaca ayat dan sudah dilakukan dengan baik oleh guru sesuai dengan etika mengajar.
\end{abstract}

Kata Kunci: Pendidikan karakter, PAI. Sekolah Dasar

Abstract

The purpose of this research is to describe the implementation of the Character Education (PPK) program in $P A I$ subjects in terms of planning, implementation, and evaluation in elementary schools. The method used in this research is descriptive qualitative by using data collection techniques through interviews, observation and documentation. Then the data analysis techniques used are data reduction, data presentation and conclusions. The results of this study In making character education plans for Islamic religious education subjects, teachers include many expected character values in the learning implementation plan (RPP). 'at, mutual cooperation, takziah for those who experience misfortune, as well as the provision of clean water and prayer tools to practice prayer at school. The form of evaluation carried out for students is to work on Student Worksheets (LKS) and practice reading verses and has been done with by the teacher in accordance with teaching ethics.

Keywords: Character education, PAI. Primary school

Copyright (c) 2021 Titin Lestari Solehat, Zaka Hadikusuma Ramadan

Corresponding author :

Email : titinlestari@student.uir.ac.id

DOI : https://doi.org/10.31004/basicedu.v5i4.1202 
2271 Analisis Program Penguatan Pendidikan Karakter pada Mata Pelajaran Pendidikan Agama Islam (PAI) di Sekolah Dasar - Titin Lestari Solehat, Zaka Hadikusuma Ramadan

DOI: https://doi.org/10.31004/basicedu.v5i4.1202

\section{PENDAHULUAN}

Penguatan pendidikan karakter (character education) atau pendidikan moral (moral education) dalam masa ini perlu diimplementasikan untuk mengatasi krisis moral yang sedang melanda negeri ini. Krisis tersebut antara lain adalah pergaulan bebas yang semakin meningkat, seperti penyalahgunaan obat-obatan terlarang (narkoba) dan ponografi. Selain dua kasus tersebut, saat ini juga marak terjadi kekerasan terhadap anak dan remaja, pencurian, kebiasaan menyontek, serta tawuran yang sudah menjadi masalah sosial yang sampai saat ini belum dapat diatasi secara tuntas (Maisaro,A.,Wiyono,B.B.,Arifin, 2018).

Penguatan karakter bangsa menjadi salah satu tugas utama dan sebagai bentuk pelaksanaan tugas yang telah diarahkan oleh Presiden Joko Widodo melalui Gerakan Nasional Revolusi Mental (GNRM), Presiden Joko Widodo menciptakan penguatan revolusi karakter bangsa melalui budi pekerti dan pembangunan karakter peserta didik sebagai bagian dari revolusi mental. Harapan pemerintah melalui gerakan PPK ini adalah penumbuhan karakter menjadi ruh atau jiwa yang melekat dalam penyelenggaraan pendidikan dan mendorong karakter berupa sinergi antara olah hati, olah raga, olah rasa dan olah karsa yang muncul dalam lima nilai utama karakter bangsa sebagai prioritas gerakan PPK yaitu Religius, nasionalis, mandiri, gotong royong, dan integritas (Widodo, 2019).

Gerakan ini muncul sebagai bagian dari kebijakan bidang pendidikan yang tujuan terpentingnya ialah mengimplementasikan program Nawacita Presiden dalam Sisdiknas. Gerakan ini akan mendorong generasi agar memiliki kemampuan berpikir, bersikap serta bertindak dengan baik sesuai tuntutan kebutuhan bangsa, dan tuntuan perubahan zaman (Lubis, 2019). Menurut (Ainissyifa, 2014) pendidikan karakter mutlak diperlukan setiap peserta didik, dari jenjang pendidikan dasar hingga perguruan tinggi. Pendidikan ini harus ditanamkan sejak anak masih kecil melalui proses yang bertahap sesuai dengan perkembangan anak. Pendidikan karakter pada usia sekolah dasar memperoleh porsi mencapai $60 \%$ dibanding jenjang pendidikan lainnya. Hal ini dimaksudkan agar nilai-nilai karakter lebih mudah diajarkan dan melekat hingga anak-anak itu dewasa (E Rohendi, 2011).

Kepala sekolah sebagai perpanjangan tangan pemerintah menjadi penanggungjawab utama dalam menerapkannya menerapkannya sesuai dengan konteks dan kekhasan daerahnya masing-masing, namun tetap Perpres tersebut menjadi rujukan utamanya ((Nurussakinah Daulay, 2019) menurut (Kemendikbud, 2017) didalam Kurikulum 2013 sebagaimana dimaksud di atas berorientasi pada penguatan karakter siswa yang telah diperkuat oleh Peraturan Presiden Nomor 87 Tahun 2017 tentng Penguatan Pendidikan Karakter (PPK). Nilai-nilai utama PPK tersebut ditanamkan dan dipraktikan melalui sistem sekolah agar diketahui, dipahami, dan diterapkan di seluruh sendi-sendi kehidupan peserta didik. Sekolah sebagai lembaga. Pendidikan memiliki tanggungjawab untuk menanamkan dan mengembangkannilai tersebut untuk menghasilkan peserta didik yang berkarakter. (Widodo, 2019) Pendidikan dasar merupakan pendidikan lanjutan dari pendidikan keluarga, karena itu kerjasama antara sekolah dengan keluarga merupakan hal yang sangat penting. Karakter anak sangat dipengaruhi oleh lingkungan sekitar tempat anak tinggal. Lembaga sekolah saat ini menjadi tumpuan yang sangat besar dalam menguatkan pendidikan karakter melalui berbagai macam strategi, termasuk diantaranya adalah kurikulum, penegakkan disiplin, manajemen kelas, baik melalui programprogram sekolah yang sudah dirancangkan (Isbadrianingtyas,N.,Hasanah,M.,Mudiono, 2016) dengan upaya menyiapkan generasi emas pada tahun 2045 nanti yang senantiasa bertaqwa, nasionalis, tangguh dan juga mandiriadalah cita-cita bangsa Indonesia, namun perlu upaya untuk mengwujudkannya karena permasalahan sosial yang akhir-akhir ini kita dengar adalah tentang tawuran para pelajar di Indonesia. Betapa maraknya permasalah yang terkait dengan dunia pendidikan. Permasalahan yang lain diantaranya adalah degradasi moral, akhlak dan budi pekerti yang kini ada di lingkungan pendidikan, misalnya saja adalah mencotek teman pada saat ulangan, tidak patuh pada nasehat guru, tidak mau bersalaman ketika ketemu dengan guru, 
membuka pintu tanpa mengucapkan salam, tidak bertegur sapa ketika bertemu dengan guru, berbicara lantang ketika dengan orang yang lebih tua, tidak segera melakukan sholat dan masih banyak lainya.

Pendidikan karakter sebenarnya sudah lama diimplementasikan dalam pembelajaran di sekolahsekolah, khususnya dalam pendidikan agama, pendidikan kewarganegaraan, dan sebagainya. Namun dalam pelaksanaannya masih belum optimal, itu dikarenakan pendidikan karakter bukanlah sebuah proses menghapal materi soal ujian dan teknik-teknik menjawabnya. Pendidikan karakter memerlukan pembiasaan. Pembiasaan untuk berbuat baik,pembiasaan untuk berlaku jujur, kesatria, malu berbuat curang, malu bersikap malas, malu membiarkan lingkungannya kotor. Pendidikan karakter adalah sebuah proses transformasi nilainilai kehidupan untuk ditumbuhkembangkan dalam kepribadian seseorang sehingga menjadi satu dalam perilku kehidupan orang itu. (Abdul Majid, Dian Andayani, 2011) dalam definisi ini ada tiga ide pikiran penting yaitu: proses transformasi nilai-nilai, ditumbuh-kembangkan dalam kepribadian dan menjadi satu dalam perilaku. (Samani, 2013).

Karakter tidak terbentuk secara instan, tapi harus dilatih secara serius dan proporsional agar mencapai bentuk dan kekuatan yang ideal. (Kuniawan, 2016) Penguatan Penddikan Karakter (PPK) juga penting di SDN 003 Sei Emas Desa Kepenuhan Barat. Secara umum pendidikan karakter sesunguhnya sangat dibutuhkan sejak anak berusia dini. Apa bila karakter sudah terbentuk sejak anak berusia dini, ketika dewasa nanti akan mudah terpengaruh atau berubah karena adanya segala intervesi atau godaan yang datang merayu dan menggiurkan dimasa depan anak. Adapun penerepan pendidikan karakter pada mata pelajaran Agama Islam (PAI) dilakukan seperti membaca surah pendek dan surah yasin yang dibaca ketika hari jumat. Kemudian di lanjukan dengan melakukan kegiatan gotong-royong agar siswa biasa mendiri dan bertanggung jawab kepada lingkugan sekitarnya yang dimana hal tersebut ditanamkan kepada siswa secajak dini. Kemudian pendidikan Agama Islam juga diterapan didalam kelas, dimana guru sebelumpelajran dilakukan siswa di suruh memca doa.

Berdasarkan penjelasan diatas peneliti melihat di SDN 003 Sei emas Desa Kepenuhan Barat, khususnya pada mata pelajaran PAI peneliti mendapatkan informasi bahwa sekolah tersebut telah menerapkan Program PPK. Akan tetapi dari hasil wawancara peneliti dengan guru Jumai Yarti, S. Sd. I dalam pembelajaran PAI di SD tersebut, guru mengeluhkan kurangnya bimbingan yang diberikan sekolah mengenai program PPK. Selain itu, guru PAI tersebut memegang semua kelas dari kelas I sampai kelas VI, sehingga sulit bagi guru untuk menerapkan Program PPK dan penerapanya didalam kelas guru kesulitan dikarenakan siswa yang lebih asik bermain, maka dari itu guru hanya memberikan tugas agar siswa tidak bermain. Berdasarkan info awal peneliti, peneliti tertarik ingin melakukan penelitian di SD Negeri 003 Sei Emas Desa Kepenuhan Barat tersebut dengan mengangkat judul "Analisis Program Penguatan Pendidikan Karakter (PPK) pada mata pelajaran PAI di Sekolah Dasar Negeri 003 Sei Emas Desa Kepenuhan Barat Kecamatan Kepenuhan Kabupaten Rokan Hulu”.

\section{METODE PENELITIAN}

Penelitian ini menggunakan kualitatif deskriptif (Arikunto, 2013) penelitian ini mendeskripsikan implementasi Program Pendidikan Karakter (PPK) pada mata pelajaran PAI di tinjau dari Perancanaan, Pelaksanaan, dan evaluasi di Sekolah Dasar Negeri 003 Sei Emas dengan kurun waktu penelitian dari bulan September 2020-April 2021. Dalam penelitian ini yang harus dilalui oleh peneliti yaitu dimulai dengan 1) observasi awal yang dilakukan dengan cara wawancara kepada kepala sekolah untuk menjadi data awal peneliti melakukan penelitian. Obersevasi diarahkan kepada memperhatikan secara akurat, mencatat fenomena yang muncul, dan mempertimbangkan hubungan antara aspek dan fenomena yang terjadi. 2) merumuskan masalah. Setelah peneliti melakukan obervasi awal, peneliti merumuskan masalah yang tepat sesuai dengan judul yang telah peneliti ambil dan berdasarkan observasi awal yang peneliti lakukan. 3) 
pelaksanaan penelitian. Peneliti ke lapangan langsung untuk mencari data sehingga data tersebut dapat menjawab permasalahan yang peneliti angkat. Peneliti menggunakan teknik pengumpulan data observasi, wawancara dan dokumentasi. Penelitian ini digunakan teknik triangulasi sumber yang dicapai melalui cara membandingkan data hasil pengamatan dengan data hasil observasi, wawancara, dan dokumentasi.

\section{HASIL PENELITIAN DAN PEMBAHASAN}

Pendidikan Karakter adalah upaya mendidik anak supaya mereka dapat membuat keputusan dan mempraktikan secara bijaksana dalam kehidupan sehari-hari, sehingga mereka dapat berkontribusi secara positif terhadap lingkungan mereka (Yetri \& Rijal Firdaos., 2017) yang mengarah pada pencapaian dalam pembentukan karakter dan akhlak mulia siswa secara utuh, terintegrasi dan seimbang, sesuai dengan standar kompetensi. Gerakan pendidikan di sekolah untuk memperkuat karakter melalui proses pelatihan, menstransformasikan, menstransmisikan, dan mengembangkan kemampuan siswa dengan cara menerapkan (1) Nilai Religiusitas, (2) Nilai Nasionalisme, (3) Nilai Kemandirian, (4) Nilai Gotong Royong, dan (5) Nilai Integritas merupakan suatu cara penguatan pendidikan karakter di sekolah (Zulaikah, 2019) dalam Penguatan pendidikan karakter melalui Pendidikan Agama Islam terdapat tiga jalur, yang pertama memperkuat pendidikan karakter berbasis kelas. Berdasarkan data yang diperoleh, SDN 003 Sei Emas untuk mata pelajaran Pendidikan Agama Islam menggunakan program K13 di mana program ini merupakan persyaratan dengan memasukkan nilai-nilai karakter. Demikian juga, guru Pendidikan Agama Islam membuat RPP dengan mengggunakan kurikulum 2013. Penguatan ini terdiri dari mengintegrasikan K13 ke dalam kegiatan pembelajaran PAI, baik intra-kurikuler dan ekstrakurikuler. Pembelajaran PAI dan PKn memberikan dampak positif terhadap karakter peserta didik diera milenial (Lin, 2015).

Nilai-nilai dan pesan-pesan dalam materi pembelajaran diurutkan dan dipilih dan guru menganalisis keterampilan dasar yang dapat dimasukkan dalam rencana pelajaran. Misalnya, RPP kelas IV disiapkan oleh guru PAI dengan tema toleransi pada mata pelajaran PAI. Bahan belajarnya adalah ayat 13 dari Sura AlHujurat tentang Toleransi dan menghormari terhadap Perbedaan.Penerapan Pendidikan karakter dalam pembelajaran pendidikan agama Islam SDN 003 Sei Emas dilakukan disusun sejak proses perencanaan pembelajaran, pelaksanaan pembelajaran, dan diakhiri dengan evaluasi.

\section{Perencanaan Program Penguatan Pendidikan Karakter pada Mata Pelajaran Pendidikan Agama Islam SDN 003 Sei Emas}

Perencanaan merupakan komponen penting sebelum melaksanakan pembelajaran, oleh karena itu perencanaan pembelajaran harus dilakukan oleh guru sebelum mengajar. Sebagai persiapan mengajar guru mata pelajaran pendidikan agama Islam di SDN 003 Sei Emas selaku guru kelas menyusun rencana pelaksanaan pembelajaran (RPP). Dalam penyusunan rencana pelaksanaan pembelajaran yang dilakukan oleh guru, juga harus melihat visi, misi dan tujuan sekolah itu sendiri. Setelah menyesuaikan perencanaan yang akan dibuat oleh guru dengan melihat visi, misi dan tujuan dari SDN 003 Sei Emas, langkah selanjutnya yang dilakukan oleh guru ialah mengacu pada kurikulum yang sedang digunakan di SDN 003 Sei Emas tersebut, dan kurikulum yang dipakai disana ialah kurikulum 13 dan hal ini dibenarkan oleh pernyataan kepala sekolah SDN 003 Sei Emas, beliau mengatakan bahwa sekolah sudah mengikuti kurikulum K13 yang sudah di sudah diterapkan. Perencanaan pendidikan karakter pada mata pelajaran pendidikan agama Islam tidak jauh berbeda dengan perencanaan pembelajaran pendidikan karakter pada mata pelajaran yang lain, hanya saja dalam materi mata pelajaran pendidikan agama Islam terdapat lebih banyak nilai- nilai karakter yang dapat dikembangkan dibandingkan dengan mata pelajaran yang lain. Oleh karena itu dalam membuat perencanaan pendidikan karakter mata pelajaran pendidikan agama Islam, guru banyak mencantumkan nilai-nilai karakter yang diharapkan di dalam rencana pelaksanaan pembelajaran (RPP). Proses perencanaan pembelajaran bagi pendidik dimulai dari menyusun silabus, RPP, materi pembelajaran, metode pembelajaran, media 
pembelajaran, sumber dan alat pembelajaran, alat penilaian dan menyusun lingkungan pembelajaran. Penyusunan yang dilakukan ini akan membantu pendidik dalam melanjutkan proses pelaksanaan pembelajaran di dalam dan luar kelas. Pendidik memiliki pedoman yang jelas untuk pelaksanaan pembelajaran kedepan.

Adapun kesulitan yang dihadapi oleh pendidik adalah saat menyusun rencana pembelajaran (RPP) dan silabus. Pendidik sedikit kebingungan mencantumkan poin-poin nilai-nilai karakter yang akan diintegrasikan ke materi pembelajarannya membantu dalam proses perencanaan pembelajaran yang maksimal. Seorang pendidik harus menguasai karakter yang akan diajarkan kepada (Rissanen, I., Kuusisto, E., Hanhimäki \& \& Tirri, 2018) peran pendidik sangat penting dalam membentuk karakter siswa melalui proses pembelajaran (Berkowitz, 2018) pendidikan karakter penanaman membutuhkan proses yang panjang, karena tidak diperoleh secara instan. Pendidik harus pandai mengelola strategi untuk mengintegrasikan peserta didik kompetensi, mulai dari pengetahuan dan keterampilan hingga bidang dan sikap nasional mereka (Moran, 2018).

\section{Pelaksanaan Program Penguatan Pendidikan Karakter pada Mata Pelajaran Pendidikan Agama Islam SDN 003 Sei Emas}

Persiapan yang ditetapkan dan difasilitasi oleh sekolah adalah seperti membaca surah pendek dan yaasin pada hari Jum'at, gotong royong, takziah bagi yang mengalami kemalangan, serta penyediaan air bersih dan alat shalat untuk melakukan praktek shalat di sekolah. Hal ini sesuai dengan hasil wawancara sebagai berikut. Persiapan yang dilakukan sekoah untuk mengebangkan pendikan karakter, seperi pada hari jumat melakukan membaca surah pendek dan yasin, dan juga melakukan kegitaan goto royong, dan ada juga jika siswa maupun guru jika terdapat kemalangan siswa maunpun guru pergi takziah kerumah yang mendat kemalangan (Kepala Sekolah). Hal yang akan disiapkan ketika pemblajaran dialam kelas contohnya: melaksanakan praktek sholat alat yang akan di persiapkan seperti, Air bersih, Sejadah, mokenah, dan peci (Guru Agama Islam). Selain itu, dalam pelaksanaan pengembangan rencana pembelajaran, penekanannya adalah pada peningkatan karakter dengan menunjukkan pilihan metode pembelajaran dan sumber pembelajaran. Di sini, guru menggunakan metode diskusi, ceramah dan praktek. Hal ini sesuai dengan wawancara Guru Agama Islam bahwa Metode yang biasa di gunakan adalah Metode diskusi, Metode ceramah, Metoda Percobaan/Paraktek.

Menurut (Zulaikah, 2019) untuk mendukung pengimplementasian model ini, guru bisa menggunakan metode tanya jawab, wawancara, diskusi, dan bermaina peran (praktek). Model tanya jawab terdiri dari penyampaian pesan pendidikan dengan mengajukan pertanyaan dan siswa memberikan jawaban atau sebaliknya, siswa memiliki kesempatan untuk mengajukan pertanyaan dan guru menjawab pertanyaan. Model wawancara adalah model untuk memperoleh informasi dengan mengajukan pertanyaan langsung kepada siswa. Model diskusi adalah sarana untuk menyajikan materi pelajaran ketika guru memberi siswa (kelompok siswa) kesempatan untuk mengadakan pembicaraan ilmiah untuk mengumpulkan pendapat, menarik kesimpulan atau mengatur berbagai solusi untuk memecahkan suatu masalah. Metode role play adalah suatu bentuk model pembelajaran dari game edukasi yang digunakan untuk menjelaskan perasaan, sikap, perilaku dan nilai-nilai, dalam rangka menghargai perasaan, pandangan dan cara berpikir orang lain. Kerja sama, solidaritas, gotong royong dan kekeluargaan adalah nilai- nilai yang memperkuat karakter yang diwujudkan. Dalam RPP juga dijelaskan kegiatan pembelajaran dasar yang menggabungkan nilai-nilai pembangunan karakter. Misalnya, kegiatan literasi terdiri dari melihat, menonton, membaca, dan bermain dalam RPP untuk menumbuhkan sikap mandiri siswa. Mereka juga dilatih dengan bekerja sama melalui diskusi. Selama diskusi, siswa juga dilatih dalam kemandirian dan kepercayaan diri untuk meneliti dan mengumpulkan informasi dan kemudian menyajikan kembali materi pembelajaran yang sesuai untuk meningkatkan pengetahuan dan keberanian mereka dengan pertukaran informasi antara masing-masing kelompok.

Selain menggunakan metode role playing, ada juga beberapa metode yang dapat digunakan seperti metode keteladanan dan pembiasaan seperti hasil penelitian yang dilakukan oleh (Haidir et al., 2020) yang 
menyatakan bahwa dalam hal penggunaan metode para guru dapat mempergunakan beberapa metode yang berkenaan dengan ranah sikap, seperti metode keteladanan dan metode pembiasaan. Karakter pada dasarnya tidak cukup hanya diajarkannya, melainkan yang paling penting ialah ditanamkan. Tentunya, proses penanaman itu dapat dilakukan dengan dua cara yakni keteladanan dan pembiasaan. Dengan terbiasa melakukan karakter-karakter terpuji maka dengan sendirinya secara tidak langsung ia akan memahami, dan melaksanakannya dalam kehidupan sehari-hari. Menurut (Hubbi et al., 2020) seorang pendidik perlu lebih kreatif, produktif dan memahami perannya sebagai pendidik dalam rangka membantu peserta didiknya melalui pembelajaran dan pembiasaan karakter sehari-hari untuk menanamkan nilai-nilai karakter tersebut. Menggunakan metode-metode pembelajaran yang lebih kreatif, segar dan baru di dalam kelas serta pendidik di harapkan lebih produktif dalam mengembangkan kualitas pengetahuannya di bidang pengasuhan peserta didik dan pendidikan

\section{Evaluasi Program Penguatan Pendidikan Karakter pada Mata Pelajaran Pendidikan Agama Islam SDN 003 Sei Emas}

Evaluasi dalam proses pendidikan karakter dalam Pendidikan Agama Islam di SDN 003 Sei Emas dilakukan untuk mengetahui sejauh mana kemampuan peserta didik menguasai materi pendidikan agama islam khususnya dalam pengembangan dan penguatan pendidikan karakter peserta didik, di lakukan dengan hasil pengamatan, laporan tugas yang dilakukan oleh guru. Berdasarkan hasil wawancara, bentuk evaluasi yang dilakukan bagi peserta didik adalah dengan pengerjaan Lembar Kerja Siswa (LKS) dan praktek membaca ayat dan sudah dilakukan dengan baik oleh guru sesuai dengan etika mengajar. Hasil evaluasi ini tentunya menjadi dasar bagi sekolah untuk memperbaiki, meningkatkan program penguatan Pendidikan karakter di sekolah dan tentunya memberi dampak yang baik bagi siswa. Menurut (Miftachul Huda, 2021), evaluasi penguatan pendidikan karakter berbasis pendidikan agama Islam di sekolah maka membawa dampak positif terhadap perkembangan dan pertumbuhan sekolah baik secara kelembagaan, kesiswaan, prestasi akademik dan non akademik, kualitas lulusan yang diterima diperguruan tinggi dan swasta, hal ini juga menambah kepercayaan masyarakat terhadap keberhasilan sekolah dalam melaksanakan pendidikan serta semakin memperkuat eksistensi sekolah di hadapan masyarakat luas maupun di instansi pemerintah maupun swasta.

\section{Kendala Yang Dihadapi dalam Implementasi Program Penguatan Pendidikan Karakter pada Mata Pelajaran Agama Islam SDN 003 Sei Emas}

Tidak semua guru mendapatkan sosialisasi dan pelatihan tentang penerapan program Penguatan Pendidikan Karakter oleh Kementerian Pendidikan. Sehingga bagi guru yang belum mendapatkan pelatihan tentu akan menemui kesulitan. 2) Kurangnya kerjasama antar guru. Meskipun secara umum memang pendidikan karakter banyak menjadi tanggung jawab guru PAI dan PKn namun bukan berarti guru lain tidak bertanggungjawab terhadap pendidikan karakter anak didik. 3) Kurangnya kerjasama dengan orang tua. Pendidikan karakter tentu akan berjalan sesuai target, apabila orang tua juga memberikan support terhadap perkembangan sikap anak. Jika hanya pada guru saja, maka tentu tidak akan tercapai dengan maksimal. Terbukti dalam hal ini, selalu memanggil orang tua untuk hadir namun selalu saja ada orang tua yang tidak hadir dengan berbagai alasan tertentu. Keterbatasan dalam penulisan ini kurang mengkaji tentang problema peserta didik di lingkungan sekolahaupun di luar sekolah.

\section{KESIMPULAN}

Sebagai persiapan mengajar, guru mata pelajaran pendidikan agama Islam di SDN 003 Sei Emas selaku guru kelas menyusun rencana pelaksanaan pembelajaran (RPP). Setelah menyesuaikan perencanaan yang akan dibuat oleh guru langkah selanjutnya yang dilakukan oleh guru ialah mengacu pada kurikulum yang sedang digunakan di SDN 003 Sei Emas tersebut,dan kurikulum yang dipakai disana ialah kurikulum 13 dan hal ini dibenarkan oleh pernyataan kepala sekolah SDN 003 Sei Emas, beliau mengatakan bahwa sekolah sudah mengikuti kurikulum k13 yang sudah disudah diterapkan. Dalam membuat perencanaan pendidikan karakter 
mata pelajaran pendidikan agama Islam, guru banyak mencantumkan nilai-nilai karakter yang diharapkan di dalam rencana pelaksanaan pembelajaran (RPP). Persiapan yang ditetapkan dan difasilitasi oleh sekolah adalah seperti membaca surah pendek dan yaasin pada hari Jum'at, gotong royong, takziah bagi yang mengalami kemalangan, serta penyediaan air bersih dan alat shalat untuk melakukan praktek shalat di sekolah. Bentuk evaluasi yang dilakukan bagi peserta didik adalah denganpengerjaan Lembar Kerja Siswa (LKS) dan praktek membaca ayat dan sudah dilakukan dengan baik oleh guru sesuai dengan etika mengajar.

\section{DAFTAR PUSTAKA}

Abdul Majid, Dian Andayani. (2011). Pendidikan Karakter Perspektif Islam,. Bandung: Pt. Remaja Rosdakarya.

Ainissyifa, H. (2014). 'Pendidikan Karakter Dalam Perspektif Islam'. Jurnal Pendidikan Universitas Garut,.

Arikunto, S. (2013). Prosedur Penelitian Suatu Pendekatan Praktik. Jakarta: Pt Rineka Cipta.

Berkowitz, Dkk. (2018). Educating For Positive Youth Development. In Handbook Of Moral Development (Pp. 701-720). Psychology Press, 701-720.

E Rohendi. (2011). 'Pendidikan Karakter Di Sekolah', Eduhumaniora.

Haidir, Gusman, M., \& Sari, N. K. (2020). Implementasi Program Penguatan Pendidikan Karakter (Ppk) Dalam Pembelajaran Pendidikan Agama Islam (Studi Deksriptif Di Sd Rusyda Medan). Jurnal Agama Dan Pendidikan Islam, 12(1), 45-59.

Hubbi, U., Ramdani, A., \& Setiadi, D. (2020). Integrasi Pendidikan Karakter Kedalam Pembelajaran Pendidikan Agama Islam Dan Pendidikan Kewarganegaraan Di Era Milenial. Jurnal Ilmu Sosial Dan Pendidikan, 4(3), 228-239.

Isbadrianingtyas,N.,Hasanah,M.,Mudiono, A. (2016). Pengelolaan Kelas Dalam Pembelajaran Tematik Di Sekolah Dasar. Urnal Pendidikan:Teori, Penelitian, Dan Pengembangan, 1(5), 901-904.

Kemendikbud. (2017). Panduan Penilaian Oleh Pendidik Dan Satuan Pendidikan Untuk Sekolah Menengah Atas.

Kuniawan, S. (2016). Pendidikan Karakter Konsepsi \& Implementasinya Secara Terpadu Di Lingkungan Keluarga, Sekolah, Perguruan Tinggi \& Masyarakat. Ar-Ruzz Media.

Lin, A. (2015). Citizenship Education In American Schools And Its Role In Developing Civic Engagement: $A$ Review Of The Research. Educational Review, 67(1), 35-63.

Lubis, R. R. (2019). Implementasi, Program Penguatan Pendidikan Karakter (Ppk) Dalam Pembelajaran Penddikan Afama Islam. Al-Fikru, 12(1), 21.

Maisaro,A.,Wiyono,B.B.,Arifin, I. (2018). Manajemen Program Penguatan Pendidikan Karakter Di Sekolah Dasar. Jamp: Jurnal Administrasi Dan Manajemen Pendidikan, 1(3), 302-312.

Miftachul Huda. (2021). Strategi Penguatan Pendidikan Karakter Berbasis Pendidikan Agama Islam Di Sma Islam. Jurnal Keislaman Pendidikan, 3(1).

Moran, S. (2018). Purpose-In-Action Education: Introduction And Implications.

Nurussakinah Daulay. (2019). The Dynamic Of Islamic Education In South East Asia . In Seminar Of International. Perdana Publishing.

Rissanen, I., Kuusisto, E., Hanhimäki, E., \& \& Tirri, K. (2018). The Implications Of Teachers' Implicit Theories For Moral Education: A Case Study From Finland. , 47(1), 63-77. Journal Of Moral Education, 47(1), 63-77.

Samani, M. Dan H. (2013). Konsep Dan Model Pendidikan Karakter,. Bandung: Pt Remaja Rosdakarya. 
2277 Analisis Program Penguatan Pendidikan Karakter pada Mata Pelajaran Pendidikan Agama Islam (PAI) di Sekolah Dasar - Titin Lestari Solehat, Zaka Hadikusuma Ramadan

DOI: https://doi.org/10.31004/basicedu.v5i4.1202

Widodo, H. (2019). Penguatan Pendidikan Karakter Di Sd Muhammadiyah Macanan Sleman Yogyakarta. Jurnal Lentera Pendidikan, 2(1), 40-51.

Yetri \& Rijal Firdaos. (2017). Penguatan Pendidikan Karakter Berbasis Masyarakat Pada Smpn Di Kabupaten Tulang Bawang Provinsi Lampung. Jurnal Pendidikan Islam, 8(2), 267 - 279.

Zulaikah, S. (2019). Penguatan Pendidikan Karakter Melalui Pendidikan Agama Islam Di Smpn 3 Bandar Lampung. Al-Tadzkiyyah. Jurnal Pendidikan Islam, 10(1). 